\title{
Phytotoxic potential of aqueous leaf extract of Tocoyena formosa and Rudgea viburnoides ${ }^{1}$
}

\author{
Sharmely Hilares Vargas ${ }^{2 *} \mathbb{D}$, Maria de Fátima Barbosa Coelho ${ }^{2}$, Elbert Simon Cowo ${ }^{3}$, \\ Hipolito Murga Orrillo², Carla Spiller ${ }^{2}$ \\ $10.1590 / 0034-737 X 201966050007$
}

\begin{abstract}
Plants have organic components produced as secondary metabolites able to positively or negatively interfere on normal development of other species. The objective of this research was to determine the phytotoxic effects of aqueous leaf extract from two species Rubiaceae family: Tocoyena formosa and Rudgea viburnoides on the germination and initial development of lettuce (Lactuca sativa $\mathrm{L}$ ). The extract was obtained from mixing $50 \mathrm{~g}$ of fresh leaf and $500 \mathrm{~mL}$ of distilled water. The experiment was arranged in completely randomized design for each specie, subjected to five extract concentrations: $0,25,50,75$ and $100 \%$; and 4 repetitions of 50 seed each. The bioassays were performed in laboratory at controlled temperature and luminosity during seven days. Results showed that the aqueous extract of both species do not affected the germination and the percent of abnormal lettuce seedlings. $R$. viburnoides showed no pronounced difference in relation to shoot length and dry biomass; however, the root length was reduced by $85 \%$. The extract of $T$. formosa at higher concentrations, drastically reduce the dry biomass and length of shoots and roots. Therefore, both species have phytotoxic effect on seedling growth of lettuce being the length root the most affected variable.
\end{abstract}

Keywords: Lactuca sativa L.; bioassays; aqueous extract; germination.

\section{INTRODUCTION}

The Rubiacea family has 17 genera and 727 species endemic to the Brazilian flora (Barbosa et al., 2015). The genus Tocoyena with neotropical distribution has an important role as food for wild animals (Delprete, 2008). The species Tocoyena formosa (Cham. \& Schltdl.) K. Schum popularly known as jenipapo-bravo, guamarú and genipapo-de-cavalo, is a woody species from the Brazilian cerrado distributed in rural physiognomies and cerradão (Silva Júnior \& Santos, 2005). It is considered an ornamental tree with potential use for landscaping. Commonly used in the Northeast of Brazil as an analgesic and for the treatment of cough, cystitis, kidney and heart problems. Also, the extract of different parts of the T. formosa has acaricidal, antifungal and antinociceptive properties (Santos et al., 2013; Cesário et al., 2018a).
Another genus of Rubiaceae is Rudgea, widely distributed on the coast and on the Brazilian cerrado with species of recognized medicinal properties such as Rudgea viburnoides (Cham.) Benth., popularly known as porangaba, casca-branca, congonha-do-gentio and chádo-bugre. It grows mainly on sloping, well-drained soils and sandy soils with low fertility, therefore has great ability to absorb nutrients from poor soils and it is an aluminum (Al) hyperaccumulating specie (Malta et al., 2016). It is popularly used in the Brazilian folk medicine for its properties as diuretic, hypotensive, blood depurative, antirheumatic, and antisyphilitic (Alves et al., 2004; Galdino et al., 2017).

The harmful or beneficial effect that a plant (including microorganism) exerts on another, due to the production and release of chemical compounds to the environment,

\footnotetext{
Submitted on october $23^{\text {rd }}, 2018$ and accepted on August 26th, 2019.

'This paper is part of the first author's master dissertation.

${ }^{2}$ Universidade Federal de Mato Grosso, Programa de Pós-Graduação em Agricultura Tropical, Cuiabá, Mato Grosso, Brazil. sharhilares@gmail.com; coelhomfstrela@gmail.com; leohmurga@gmail.com; carlaspiller@gmail.com

${ }^{3}$ EARTH University, Guácimo, Limón, Costa Rica. bert.cowo@gmail.com

*Corresponding author: sharhilares@gmail.com
} 
is known as allelopathy (Ferreira, 2004). These chemical compounds are secondary metabolites (allelochemicals) produced by plants that vary in quality and quantity from species to species influenced by different natural conditions to which the plants are exposed (Gatti et al., 2014). Resistance or tolerance to the allelochemicals is relatively specific, with more sensitive species than others, such as Lactuca sativa (lettuce) and Lycopersicum esculentum (tomato), which are commonly used in laboratory bioassays (Ferreira \& Aquila, 2000). Most of these compounds are water soluble and active at low concentrations, representing a potential alternative for use as herbicides in natural biological control of weeds under sustainable agricultural practices (Chung et al., 2001; Batish et al., 2007). Although many processes are involved, since the identification and selection of the compound as a mode of action, dose, persistence in the soil, toxicity to human and profitability and commercial scale, the laboratory assays of phytotoxic effect may act as a starting point for production of new bioherbicides (Soltys et al., 2013).

In the chemical characterization of $R$. viburnoides, the compounds were identified in the leaf extracts with positive reaction to tannins, flavonoids (quercetin, rutin), triterpenes (viburgenin and arjungenin) and saponins (arjunglucoside I and trachelosperosides) (Young et al., 1988; Alves et al., 2004, Almeida, 2011). In the phytochemical profile of the leaves of T. formosa, the presence of condensed tannins, saponins, fenolic acids and flavonoids was revealed (gallic acid, catechin, chlorogenic acid, caffeic acid, ellagic acid, rutin, quercetin and luteolin) which support its medicinal benefits (Cesário et al., 2018a, Cesário et al., 2018b).

Recent allelopathic studies have shown that aqueous extracts of species from Rubiaceae family have phytotoxic effects on the germination and initial growth of different target species (Frescura et al., 2013; Oliveira et al., 2014b). Therefore, the main objective of the present study was to evaluate if aqueous leaf extracts of $T$. formosa and $R$. viburnoides present a phytotoxic effect on the germination and initial growth of Lactuca sativa L., at different concentration.

\section{MATERIALS AND METHODS}

The experiment was carried out at the Seed Laboratory of the Faculty of Agronomy and Animal Science of the Federal University of Mato Grosso (UFMT), Cuiabá campus.

Leaves of Tocoyena formosa and Rudgea viburnoides were collected in a preserved area from Chapada dos Guimarães, Mato Grosso, located in the Central west of Brazil, between the geographic coordinates $15^{\circ} 10^{\prime}-15^{\circ} 30^{\prime} \mathrm{S} 55^{\circ} 40^{\prime}$ $-56^{\circ} 00 \mathrm{~W}$. The climate of the region is type Aw (Climate of Cerrado), according to Köppen classification.

The plant was identified and the material was collected from reproductive plants (7-8 age) in the month of august 2018, between 8:00 and 10:00 hours.

For the preparation of the aqueous extract, the adult and fresh leaves of each species were previously washed and disinfected for 5 minutes with $10 \mathrm{~mL}$ of $2.5 \%$ Sodium Hypochlorite, diluted in $500 \mathrm{~mL}$ of distilled water. Then, the leaves were rinsed with distilled water and gently dried with paper towel. The leaves were grounded in a blender in the proportion of $50 \mathrm{~g}$ of leaves per $500 \mathrm{ml}$ of cold distilled water (Pires \& Oliveira 2011). The extract was filtered using filter paper and stored in amber glass bottles at $18^{\circ} \mathrm{C}$ until used in the bioassays.

A completely randomized experimental design with five treatments, consisting of concentrations of leaf extract, obtained by dilution in distilled water, was used $(0 \%$ control, $25 \%, 50 \%, 75 \%$ and $100 \%$ ). Each contained four replications of 50 of lettuce seeds (Lactuca sativa L. cv Veneranda) obtained from commercial store.

$\mathrm{pH}$ was determined with a $\mathrm{pH}$-meter and the electrical conductivity (EC) was measured by the conductivity meter. From the EC values, the osmotic potential (PO) was determined using the formula proposed by Ayers \& Westcot (1985): Osmotic potential in atmosphere (ATM) = - $0.36 *$ electrical conductivity (EC). The ATM data was transformed to Osmotic Potential (MPa).

The seeds were placed in clear plastic boxes $(11 \mathrm{x} 11 \mathrm{x}$ $3 \mathrm{~cm}$ ) over two sheets of blotting paper moistened with each treatment, using the amount of 2.5 times the mass of the substrate. The boxes were capped and sealed with film paper, and kept in a BOD type germination chamber, at constant temperature of $20^{\circ} \mathrm{C}$ and photoperiod of 12 hours during seven days.

Every 24 hours the number of seeds germinated were recorded for a period of 5 days (period in which stabilization occurred). Seeds with $2 \mathrm{~mm}$ radicular protrusion were considered germinated according to the concept of physiological germination. The percentage of germination was calculated by the expression: $\mathrm{G}=(\mathrm{N} / \mathrm{A}) * 100$, where: $\mathrm{N}=$ number of germinated seeds, $\mathrm{A}=$ total number of seeds placed to germinate.

The Germination Speed Index (GSI) was determined according to Maguire (1962) by the expression: GSI $=(\mathrm{G} 1 /$ $\mathrm{N} 1)+(\mathrm{G} 2 / \mathrm{N} 2)+\ldots+(\mathrm{Gn} / \mathrm{Nn})$, where: $\mathrm{G} 1, \mathrm{G} 2, \mathrm{Gn}=$ number of seeds germinated at the first count, at the second count and at the last count; and N1, N2, Nn = number of days of sowing the first, second and last count.

Seedlings were classified as normal or abnormal according to the specifications of Brasil (2009). Abnormal plants were those that showed no potential to continue their development, with rotten, absent, totally atrophied 
root or aerial systems. Therefore, seedlings with small defects, such as limited or small damage, and delayed growth in the root system were considered normal.

At the end of germination test (5 days after the experiment), normal lettuce seedlings were evaluated for shoot length: root transition region up to cotyledon insertion, and root length: shoot transition region up to the apex of the root; with the aid of a graduated ruler in centimetres. In order to determine the dry mass, the normal seedlings of each replicate were dried in the oven with forced air circulation at $65{ }^{\circ} \mathrm{C}$, where it remained until reaching constant weight. After this period, the samples were placed to cool in desiccators for approximately 60 minutes and weighed in an analytical balance $(0,001 \mathrm{~g})$.

The Allelopathic Index (IR) suggested by Williamson \& Richardson (1988) was calculated, according to: $\mathrm{IR}=1$ $\mathrm{C} / \mathrm{T}(\mathrm{T} \mathrm{e}$ " $\mathrm{C})$ or $\mathrm{RI}=\mathrm{T} / \mathrm{C}-1(\mathrm{~T}<\mathrm{C})$ where $\mathrm{C}=$ control germination speed $(0 \%)$ and $\mathrm{T}=$ Treatment speed germination.

The results were subjected to ANOVA, and means were compared by Tukey test at $5 \%$ of probability. Polynomial regressions were adjusted, and the choice was based on significance $(p<0.05)$ and on the coefficient of determination (R2). The analysis was carried out using the statistical program SISVAR (Ferreira, 2010).

\section{RESULTS AND DISCUSSION}

It was verified that the $\mathrm{pH}$ values of the aqueous leaf extracts of the germination bioassays ranged from 4.95 to 5.12 for the species Rudgea viburnoides and from 4.99 to 5.01 for Tocoyena formosa, considered acidic when compared to the control ( $\mathrm{pH}$ 7). The osmotic potential obtained for the aqueous leaf extract of $R$. viburnoides and T. formosa at different concentrations varied between -0.007 and $-0.024 \mathrm{MPa}$ respectively, being similar values in the two species (Table1).
According to Gatti et al., (2004), solutions with osmotic potential smaller or close to - $0.2 \mathrm{MPa}$ do not interfere in the germination of lettuce seed. The importance of $\mathrm{pH}$ control and the osmotic concentration of the crude extracts is essential in germination tests in laboratory, because there may be osmotically active substances in them that influence $\mathrm{pH}$ such as aminoacids, sugars and organic acids inhibiting germination and masking the allelopathic effect (Ferreira \& Aquila, 2000).

The physical-chemical parameters evaluated were within the limits considered adequate for seed germination indicating that at $\mathrm{pH}$ values below 3 or above 10, germination could be affected or completely inhibited (Chachalis \& Reddy, 2000). Therefore, it was considered that both the acidity and the osmotic potential of the aqueous extracts did not interfere in the observed results.

The germination ranged from 88 to $100 \%$, with no significant difference between doses for the two species evaluated. In addition, there was no difference on the speed germination (GSI) calculated in the concentrations evaluated for both $R$. viburnoides and T. formosa, the results varied between 21.1 and 23.9; and the percentage of abnormal seedlings ranged from 0 to $12 \%$, being not different from the control (distilled water).

Germination is the parameter less sensitive to the effect of the allelochemicals, which could be influenced by the season of the year that the collection of the material was made and the distribution of the germination curve. Thus, the allelopathic effect does not always affect germination, the generational behaviour of the germination curve, which is developed using the germination speed index (GSI), is important in the identification of anomalies in a normal germination development.

In this sense, germination should be monitored at intervals shorter than 24 hours, so it is recommended every 8 or 12 hours (Ferreira \& Aquila, 2000).

Table 1: Hydrogen potential $(\mathrm{pH})$ and Osmotic Potential (MPa) from aqueous leaf extract of Rudgea viburnoides and Tocoyena formosa, Cuiabá, MT. 2018

\begin{tabular}{lccc}
\hline Species & Extract concentration & $\mathbf{p H}$ & (MPa) \\
\hline & $0 \%$ & 7.00 & -0.0010 \\
Rudgea viburnoides & $25 \%$ & 5.12 & -0.0076 \\
& $50 \%$ & 5.02 & -0.0127 \\
& $75 \%$ & 4.95 & -0.0180 \\
& $100 \%$ & 5.00 & -0.0237 \\
\hline \multirow{2}{*}{ Tocoyena formosa } & $0 \%$ & 7.00 & -0.0010 \\
& $25 \%$ & 4.99 & -0.0077 \\
& $50 \%$ & 5.01 & -0.0131 \\
& $75 \%$ & 5.00 & -0.0182 \\
\hline
\end{tabular}

Rev. Ceres, Viçosa, v. 66, n.5, p. 380-386, sep/oct, 2019 
In this sense, germination should be monitored at intervals shorter than 24 hours, so it is recommended every 8 or 12 hours (Ferreira \& Aquila, 2000).
According to Silveira et al. (2012), there was no significant difference in germination, Mean Germination Time and Germination Speed Index (GSI) in the concentrations of the stem extract of $M$. tenuiflora on

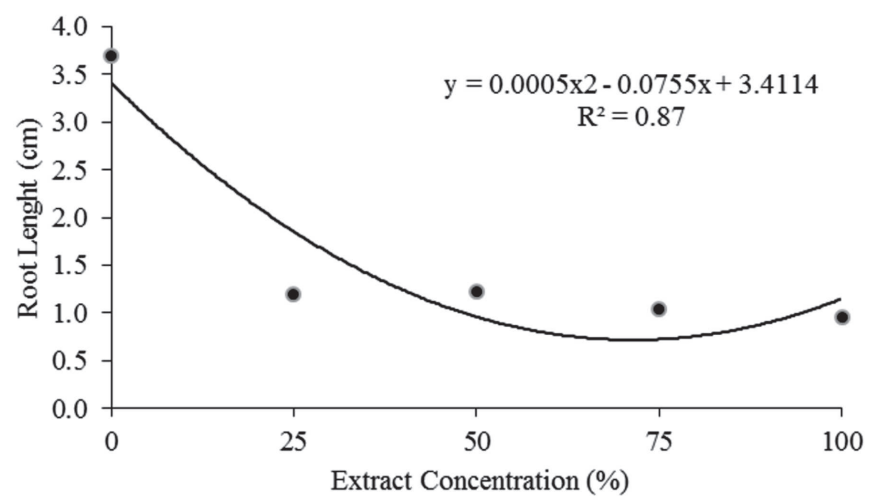

Figure 1: Root length of the initial growth of lettuce seedlings germinated at different concentrations of leaf extracts of Rudgea viburnoides. Cuiabá, MT 2018.
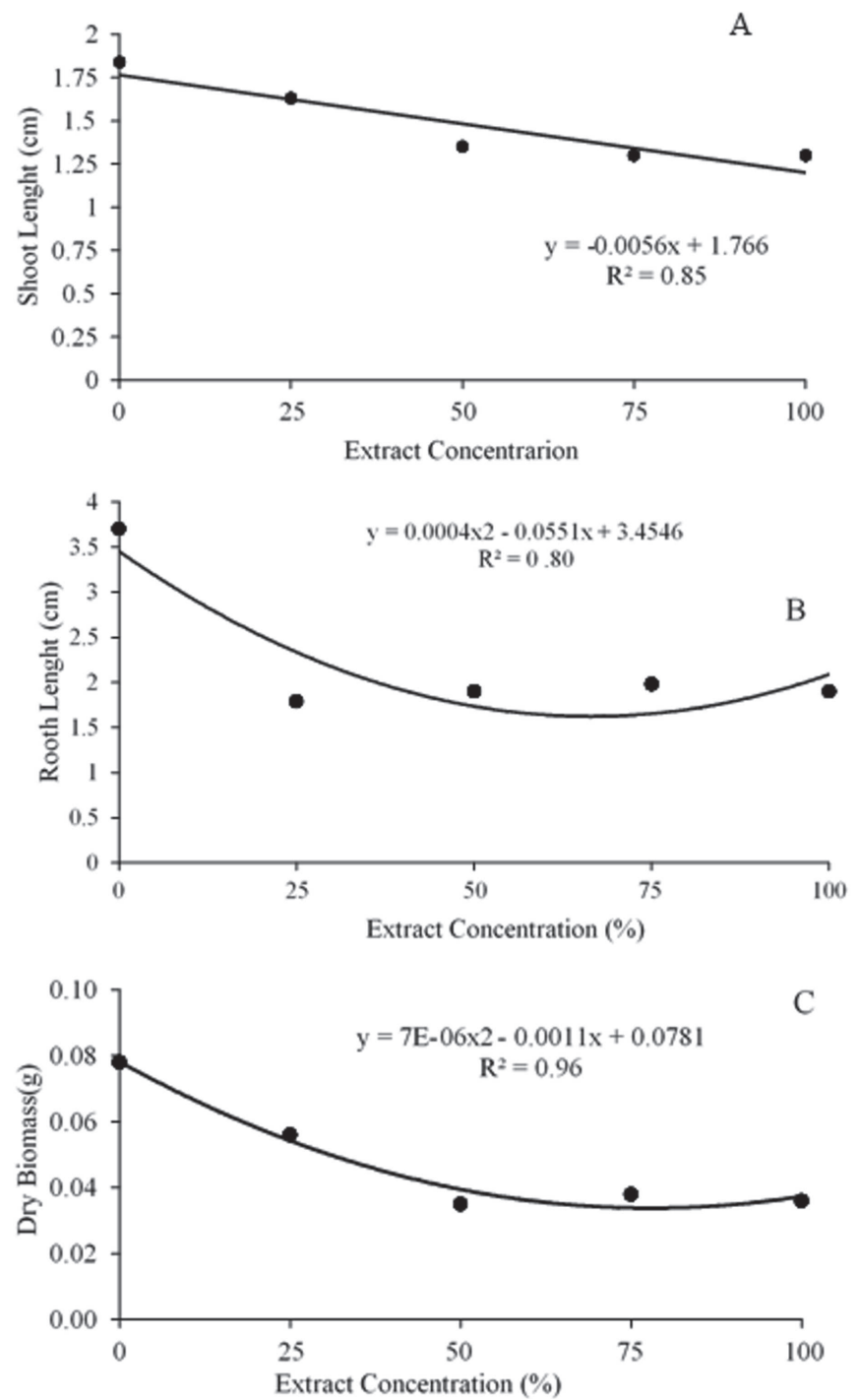

Figure 2: Shoot length (A), root length (B) and dry biomass (C) of initial growth of lettuce seedlings germinated at different concentrations of leaf extracts of Tocoyena formosa. Cuiabá, MT 2018. 
lettuce germination; but showed a phytotoxic effect on seedling initial development. Also, in another study by Oliveira et al. (2014a) with aqueous stem extract of the Pouteria ramiflora, lettuce germination was not influenced even though the root length was reduced more than $80 \%$.

The initial development of lettuce seedlings was affected by aqueous leaf extracts in both species. For $R$. viburnoides the root length was reduced by $74 \%$ from the extract concentration of $25 \%$ in relation to the control treatment $(0 \%)$, with minimal influence between the lengths with the increase of extract concentrations. This variation can be explained by the polynomial regression model of second degree with coefficient of determination (R2) greater than $86 \%$ (Figure 1). However, there was no difference in shoot length in the different treatments for the $R$. viburnoides species. Similar results were demonstrated by Oliveira et al. (2015) when evaluating extracts of Helianthus annuus, Brachiaria brizanthae and Sorghum bicolor was reduced the growing of root of different target species.

For T. formosa, both root and shoot length were reduced on contact with extracts. Smaller shoot length (Figure 2A) was observed, at higher concentration reaching the linear model with the coefficient of determination $\left(\mathrm{R}^{2}\right)$ of $85 \%$. However, the root length (Figure 2B) was affected more by the extract, than the shoot, in relation to the control, and the maximum values were reduced from $52 \%$ for root and $30 \%$ for shoot. This reduction in length was reflected in the dry seedling biomass, which was decreased as the aqueous extract concentration increased (Figure 2C).

Inhibition of root growth should be considered satisfactory to verify the existence of phytotoxic potential. These results were congruent with those obtained by Gusman et al. (2012) in bioassays with aqueous leaf extracts of different medicinal plants on the initial growth of lettuce that demonstrated a more pronounced allelopathic effect on root length than on aerial part. Chung et al. (2001) suggest that the difference between these effects is due to the direct and more prolonged contact of the root with the medium containing the allelochemical compounds, than the other parts of the plant. On the other hand, Magiero et al. (2009) found that the root is the organ most sensitive to the effect of the allelochemicals because its elongation depends on the cell division that, if inhibited, the normal development of the seedling is considerably compromised.

In general, the effects caused by allelochemicals tend to be concentration-dependent, that is, they tend to be more pronounced at higher concentrations, and this tendency is observed in the initial growth bioassays in recent studies with leaf extract of Kielmeyera coriacea, Canavalia ensiformis and Anacardium humile, on $L$. sativa (Santos et al., 2015; Pereira et al., 2018; Matias et al., 2018).

Based on the phytotoxic characterization of T. formosa and $R$. viburnoides detailed above, it is possible to associate the phytotoxic effects observed in the study with the type
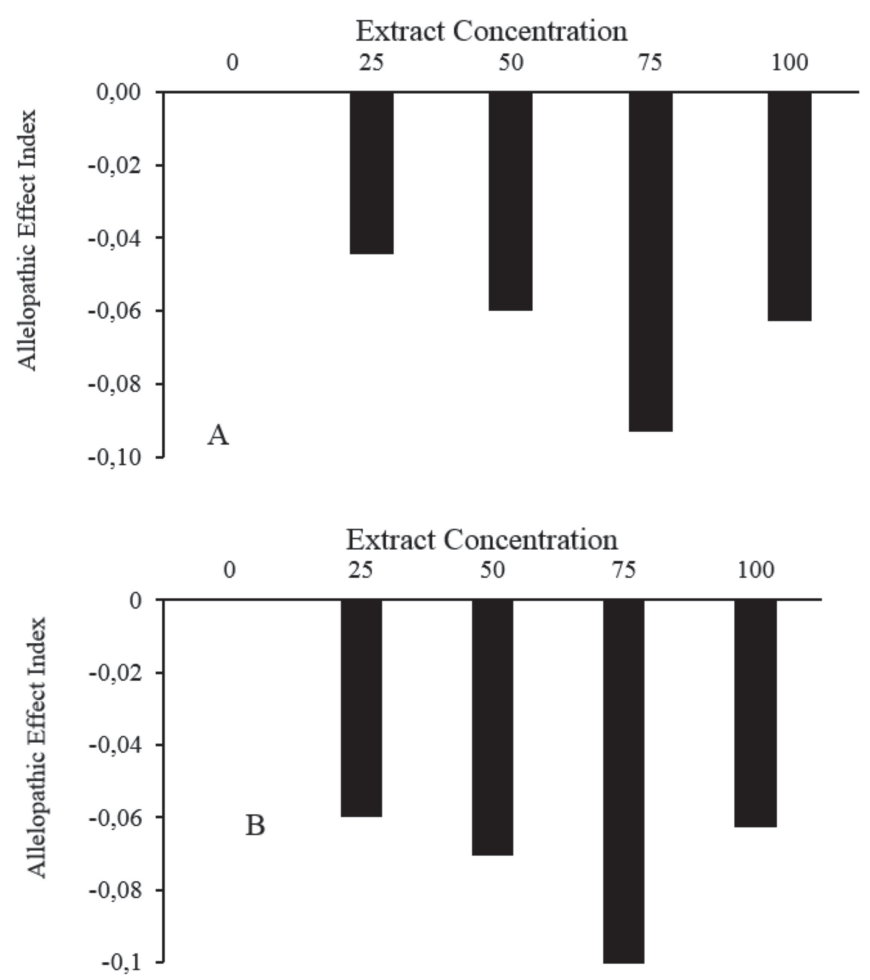

Figure 3: Influence of the extract of Rudgea viburnoides (A) and Tocoyena formosa (B) on the Allelopathic Index (IR) in achenes of Lactuca sativa L. Cuiabá, MT 2018. 
of allelochemicals present in the aqueous extract. Gallic acid is an allelochemical with a strongly inhibitory effect on root length and shoot; however, catechin inhibits plant growth to a lesser extent as reported by Iqbal et al. (2003) that evaluated the allelopathic potential of buckwheat (Fagopyrum esculentum) on weeds.

On the other hand, Golisz et al. (2007) demonstrated that rutin at high concentrations has a strong inhibitory effect on lettuce seedlings growth; therefore, it is important to know the amount of the compound present in the species studied to determine the allelochemical responsible for the observed phytotoxic effect.

The allelopathic index (IR) of the extract of the two species was inhibitory (Figure $3 \mathrm{~A}$ and $\mathrm{B}$ ), being higher in the extract concentration of $75 \%$. For both extracts as the concentration of $25 \%$ to $75 \%$ was increased, greater inhibitions were evidenced; however, in the $100 \%$ concentration the allelopathic index was reduced.

In order to evaluate the allelopathic index (IR) of Tagetes erecta L. on the germination of several crops, Quispe et al. (2010) observed that, as the concentration of the aqueous extract increased, had a greater inhibitory effect on lettuce, cucumber and radish germination; however, it had a stimulating effect on beans. Therefore, the concentration of the extract is of paramount importance in this type of experiments.

\section{CONCLUSION}

The aqueous leaf extracts of both species, Tocoyena formosa and Rudgea viburnoides did not affected any parameter of the germination, however it cause phytotoxicity on the initial growth of lettuce seedlings, being the root the part most sensible to the allelochemicals.

\section{AKNOWLEDGEMENTS, FINANCIAL SUPPORT AND FULL DISCLOSURE}

The authors are grateful to CAPES for the financial support of to master studies of the first author. They also thank the Seed Laboratory of Universidade Federal de Mato Grosso (UFMT) for providing facilities, necessary equipment and materials used in the bioassays. The authors informed that there is no conflict of interests in carrying the research and publishing this manuscript.

\section{REFERENCES}

Almeida JMAD (2011) Potencial das folhas de Rudgea viburnoides (cham.) benth (rubiaceae) no tratamento da obesidade e suas alterações metabólicas induzidas por dieta em Camundongos Balb/c. Dissertação de Mestrado. Universidade Federal de Minas Gerais, Belo Horizonte. 119p.
Alves RMS, Stehmann JR, Isaías RMS \& Brandão MGL (2004) Caracterização botânica e química de Rudgea viburnoides (Cham.) Benth., (Rubiaceae). Revista Brasileira de Farmacognosia, 14:49-56.

Ayers RS \& Westcot DW (1985) Water quality for agriculture. Rome, Food and Agriculture Organization of the United Nations. $97 \mathrm{p}$.

Barbosa MR, Zappi D, Taylor C, Cabral E, Jardim JG, Pereira MS, Calió MF, Pessoa MCR, Salas R, Souza EB, Di Maio FR, Macias L, Anunciação EA, da Germano Filho P, Oliveira JA, Bruniera CP, Gomes M, De Toni K \& Firens M (2015) Rubiaceae in Lista de Espécies da Flora do Brasil. Disponível em: <http:// floradobrasil.jbrj.gov.br/jabot/floradobrasil/FB210>. Accessed on: September $18^{\text {th }}, 2018$.

Batish DR, Singh HP, Setia N, Kohli RK, Kaur S \& Yadav SS (2007) Alternative control of littleseed canary grass using eucalypt oil. Agronomy for Sustainable Development, 27:171-177.

Brasil (2009) Regras para análise de sementes. Brasilia, MAPA / ACS. 395p.

Cesário FRAS, Albuquerque TRD, Lacerda TMD, Oliveira MRCD, Silva BAFD, Rodrigues LB, Martins AOBPBM, Almeida JRSG, Vale ML, Coutinho HDM \& Menezes IRAD (2018a) Chemical fingerprint, acute oral toxicity and anti-inflammatory activity of the hydroalcoholic extract of leaves from Tocoyena formosa (Cham. and Schlecht.) K. Schum. Saudi Journal of Biological Sciences, 26:01-08.

Cesário FRAS, de Albuquerque TR, de Lacerda GM, de Oliveira MRC, Rodrigues LB, Martins AOBPB, Boligon AA, Júnior LJQ, Araújo AADS, Vale ML, Coutinho HDM \& Menezes IRAD (2018b) Phytochemical profile and mechanisms involved in the anti-nociception caused by the hydroethanolic extract obtained from Tocoyena formosa (Cham. \& Schltdl.) K. Schum (Jenipapo-bravo) leaves in mice. Biomedicine \& Pharmacotherapy, 97:321-329.

Chachalis D \& Reddy KN (2000) Factors affecting Campsis radicans seed germination and seedling emergence. Weed Science, 48:212-216.

Chung IM, Ahn JK \& Yun SJ (2001) Assessment of allelopathic potential of barnyard grass (Echinochloa crus-galli) on rice (Oryza sativa L.) cultivars. Crop protection, 20:921-928.

Delprete PG (2008) Revision of Tocoyena (Rubiaceae: Gardenieae) from the states of Goiás and Tocantins and a new species endemic to white-sand areas in the brazilian cerrado. Journal of the Botanical Research Institute of Texas, 2:983-993.

Ferreira AG \& Aquila MEA (2000) Alelopatia: uma área emergente da ecofisiologia. Revista Brasileira de Fisiología Vegetal, 12:175-204.

Ferreira AG (2004) Interferência: competição e alelopatia. In: Ferreira AG \& Borghetti F (Eds.) Germinação: do básico ao aplicado. Porto Alegre, Artmed. p. 251-262.

Ferreira DF (2010) Programa computacional Sisvar. Versão 5,6. Lavras, UFLA. CD-ROM.

Frescura VDS, Kuhn AW, Laughinghouse IV HD, Nicoloso FT, Lopes SJ \& Tedesco SB (2013) Evaluation of the allelopathic, genotoxic, and antiproliferative effect of the medicinal species Psychotria brachypoda and Psychotria birotula (Rubiaceae) on the germination and cell division of Eruca sativa (Brassicaceae). Caryologia, 66:138-144.

Galdino PM, Alexandre LN, Pacheco LF, Junior RDSL, de Paula JR, Pedrino GR, Xavier CE \& Ferreira PM (2017) Nephroprotective effect of Rudgea viburnoides (Cham.) Benth leaves on gentamicin-induced nephrotoxicity in rats. Journal of ethnopharmacology, 201:100-107. 
Gatti AB, Takao LK, Pereira VC, Ferreira AG, Lima MIS \& Gualtieri SCJ (2014) Seasonality effect on the allelopathy of cerrado species. Brazilian Journal of Biology, 74:64-69.

Gatti AB, Perez SCJGA \& Lima MIS (2004) Atividade alelopática de extratos aquosos de Aristolochia esperanzae O. Kuntze na germinação e no crescimento de Lactuca sativa L. e Raphanus sativus L. Acta Botânica Brasílica, 18:459-472.

Golisz A, Lata B, Gawronski SW \& Fujii Y (2007) Specific and total activities of the allelochemicals identified in buckwheat. Weed Biology and Management, 7:164-171.

Gusman GS, Vieira LR \& Vestena S (2012) Alelopatia de espécies vegetais com importância farmacêutica para espécies cultivadas. Biotemas, 25:37-48.

Iqbal Z, Hiradate S, Noda A, Isojima Si \& Fujii Y (2003) Allelopathic activity of buckwheat: isolation and characterization of phenolics. Weed science, 51:657-662.

Magiero EC, Assmann JM, Marchese JA, Capelin D, Paladini MV \& Trezzi MM (2009) Efeito alelopático de Artemisia annua L. na germinação e desenvolvimento inicial de plântulas de alface (Lactuca sativa L.) e leiteiro (Euphorbia heterophylla L.). Revista Brasileira de Plantas Medicinais, 11:317-324.

Maguire JD (1962) Speed of germination-aid in selection evaluation for seedling emergence and vigor. Crop Science, 2:176-177.

Malta PG, Arcanjo-Silva S, Ribeiro C, Campos NV \& Azevedo AA (2016) Rudgea viburnoides (Rubiaceae) overcomes the low soil fertility of the Brazilian Cerrado and hyperaccumulates aluminum in cell walls and chloroplasts. Plant and soil, 408:369384 .

Matias R, Oliveira AKM, Pereira KCL, Rizzi ES \& Rosa AC (2018) Potencial alelopático do extrato etanólico de Anacardium humile (cajuzinho-do-cerrado) na germinação e formação de plântulas de alface, tomate e fedegoso. Gaia Scientia, 12:144160 .

Oliveira AK, Pereira KC, Muller JA \& Matias R (2014a) Análise fitoquímica e potencial alelopático das cascas de Pouteria ramiflora na germinação de alface. Horticultura Brasileira, 32:41-47.
Oliveira AKMD, Matias R, Lopes SS \& Fontoura FM (2014b) Allelopathy and influence of leaves of Palicourea rigida (Rubiaceae) on seed germination and seedling formation in lettuce. Bioscience Journal, 30:938-947.

Oliveira J, Peixoto C, Poelking V \& Almeida A (2015) Avaliação de extratos das espécies Helianthus annuus, Brachiaria brizanthae, Sorghum bicolor com potencial alelopático para uso como herbicida natural. Revista Brasileira de Plantas Medicinais, 17:379-384.

Pereira JC, de Albuquerque Paulino CL, da Silva Granja B, Santana AEG, Endres L \& Souza RC (2018) Potencial alelopático e identificação dos metabólitos secundários em extratos de Canavalia ensiformis L. Revista Ceres, 65:243-252.

Pires NM \& Oliveira VR (2011) Alelopatia. In: Oliveira Jr. RS, Constantin J \& Inoue MH (Eds.) Biologia e Manejo de Plantas Daninhas. Curitiba, Omnipax. p.95-123.

Quispe FE, Ruíz RE, Isidrón MP, García MR \& Santana RC (2010) Efecto alelopático de los extractos acuosos de Tectona grandis L. y Tagetes erecta L. sobre la germinación de cultivos de interés agrícola. Centro Agrícola, 37:61-66.

Santos LBD, Souza JK, Papassoni B, Borges DGL, Junior GAD, Souza JMED, Carollo CA \& Borges FDA (2013) Efficacy of extracts from plants of the Brazilian Pantanal against Rhipicephalus (Boophilus) microplus. Revista Brasileira de Parasitologia Veterinária, 22:532-538.

Santos VHMD, Daneluzzi GS, Silva LP \& Silva RMGD (2015) Evaluation of allelopathic potential of leaf extract of Kielmeyera coriacea on Lactuca sativa L. Bioscience Journal, 31:259-267.

Silva Júnior MC \& dos Santos GC (2005) 100 árvores do cerrado: guia de campo. Rede de sementes do Cerrado, Brasília. 278p.

Silveira PF, Maia SSS \& Coelho MFB (2012) Potencial alelopático do extrato aquoso de cascas de jurema preta no desenvolvimento inicial de alface. Revista Caatinga, 25:20-27.

Soltys D, Krasuska U, Bogatek R \& Gniazdowska A (2013) Allelochemicals as bioherbicides - present and perspectives. IntechOpen, 2013:517-542.

Williamson GB \& Richardson D (1988) Bioassays for allelopathy: measuring treatment responses with independent controls. Journal of chemical ecology, 14:181-187.

Young MCM, Araújo AR, da Silva CA, Lopes MN, Trevisan LMV \& Bolzani VDS (1998) Triterpenes and Saponins from Rudgea viburnioides. Journal of Natural Products, 61:936-938. 